\title{
Kajian Semiotika Roland Barthes terhadap Simbol Perempuan dalam Al-Qur'an
}

\section{Asep Mulyaden ${ }^{*}$}

1 Magister Ilmu Al-Qur'an dan Tafsir UIN Sunan Gunung Djati Bandung, Indonesia; asepmulyaden@gmail.com

* Correspondence

Received: 2021-07-30; Accepted: 2021-08-12; Published: 2021-08-17

\begin{abstract}
Abstrak: Artikel ini dibuat bertujuan untuk meneliti simbol perempuan dalam al-Qur'an. Karena para perempuan sejak dahulu hingga sekarang, selalu mendapatkan diskriminasi dan belum mendapatkan kesetaraan. Untuk mencari jawaban dari al-Qur'an, penulis mencarinya dengan pendekatan semiotika Roland Barthes yang berpandangan bahwa segala sesuatu bisa didekati dengan dua tahapan, yaitu tahap pertama disebut sistem linguistik dan tahap yang kedua disebut sistem mitis (mitos). Mitos dalam pandangan Barthes diasumsikan sebagai sistem penanda yang dibangun berdasarkan tiga hal, yaitu penanda (signifier), petanda (signified), dan tanda (sign). Berdasrkan pendekatan teori Barthes pada simbol zauj, imraah, dan perempuan sebagai ratu, maka sebenarnya perempuan dan laki-laki memiliki persamaan dan perbedaan. Pada satu keadaan mereka sama, tetapi pada keadaan lain mereka berbeda. Mereka memiliki persamaan dalam hal asal kejadiannya, yaitu sama-sama dari tanah, kesamaan dari setatus sebagai manusia, persamaan dalam hal tanggung jawab, persamaan dalam hal kelayakan pekerjaan, dan lain sebagainya. Namun dari segi tugas dan tanggung jawab, dari segi fisik, mental keduanya memiliki perbedaan.
\end{abstract}

Kata Kunci: Pendekatan teoretis; peran perempuan; sistem linguistik; status manusia; tema al-Qur'an.

\begin{abstract}
This article aims to examine the symbol of women in the Qur'an. Because women have always been discriminated against and have not received equality, to find answers from the Qur'an, the author looks for it with the semiotic approach of Roland Barthes, who holds that everything can be approached in two stages; namely the first stage is called the linguistic system and the second stage is called the mythical system (myth). In Barthes's view, Myth is assumed to be a signifying system built on three things: the signifier, the signified, and the sign. Based on Barthes' theoretical approach to the symbols of zauj, imra'ah, and women as queens, women and men have similarities and differences. In one case, they are the same, but in another, they are different. They have similarities in origin, namely both from land, similarity in status as humans, equality in terms of responsibilities, job eligibility, and the like. But in terms of duties and obligations, in terms of physical, mental both have differences.
\end{abstract}

Keywords: Human status; linguistic system; themes of Al-Qur'an; theoretical approach; women's roles.

\section{Pendahuluan}

Berdasarkan Undang Undang Dasar 1945 dan Pancasila, bahwa tujuan dari Pembangunan Nasional adalah untuk mewujudkan masyarakat yang adil dan makmur secara merata, baik secara material maupun secara spiritual. Yang menjadi sasarannya adalah pembangunan Indonesia dan pembangunan seluruh rakyatnya. Berdasarkan landasan di atas, maka pembangunan dari sector keagamaan yang ada dalam GBHN 1998 dimaksudkan kepada pengamalan tentang ajaran agama. Karena pembangunan semakin meningkat dan semakin bertambah luas, maka kepercayaan terhadap Tuhan Yang Maha Esa dan kehidupan beragama pun harus semakin diamalkan, baik dalam kehidupan individu maupun sosial kemasyarakatan (Sudarmono, 1998). 
Agama Islam merupakan agama yang memiliki dua sumber utama yang menjadi landasan keagamaan, yaitu al-Qur'an dan Sunnah Nabi. Namun untuk memahami al-Qur'an maupun hadits diperlukan pengkajian secara mendalam, bahkan ada syarat-syarat tertentu yang ditetapkan oleh para ulama bagi ornga yang ingin menafsirkan al-Qur'an, diantaranya adalah penguasaan terhadap Bahasa Arab dan yang utama adalah memiliki akidah yang benar (Al-Syuyuthi, 2008). Oleh sebab itu, maka selain meningkatkan keimanan yang kokoh dan pengembangan ilmu-ilmu keislaman, kita harus melakukan penelitian terhadap makna-makna yang terkandung dalam al-Qur'an.

Al-Qur'an merupakan kitab suci yang diturunkan kepada Nabi Muhammad saw. yang merupakan pentunjuk bagi manusia (Qs. Al- Baqarah ayat kedua), sehingga ia dapat membedakan antara yang baik dan yang buruk, termasuk menerima atau menolak apa yang dinisbahkan kepada Nabi saw. (Muththalib, n.d.).

Al-Qur'an diturunkan dengan menggunakan Bahasa Arab, yang mana nilai sastranya sangat tinggi, shingga hanya orang-orang yang memiliki pengetahuan yang tinggi yang dapat memahami kandungannya secara baik. Yaitu orang-orang yang menguasai Bahasa Arab dari berbagai aspek serta memahami 'Ulum al-Qur'an dan ilmu-ilmu bantu yang lainnya yang dibutuhkan dalam memahami alQur'an (Taufik, 1989).

Salah satu kajian yang sangat penting dari dahulu hingga sekarang adalah tentang perempuan. Bahkan ada yang berpandangan bahwa abad 21 merupakan abad perempuan. Sehingga K.H. Ahmad Dahlan berpendapat bahwa perempuan harus dilibatkan dalam perjuangan. Ia meyakini bahwa tanpa perempuan sebuah perjuangan tidak akan berhasil. Oleh sebab itu maka ia mendirikan "Aisyiyah" sebagai bukti bahwa kerjaan dapur jangan sampai menghalangi kegiatan kemasyarakatan kaum perempuan. Bahkan dalam pandangan Siti Walidah (Nyai Dahlan), perempuan Islam harus bisa menjalankan peran ganda, yaitu dalam rumah tnagga ia sebagai pengendali bahtera rumah tangga dan di tengah masyarakat ia sebagai pemberantas kebodohan dan kemiskinan (Adawiah, 2013).

Sejarah telah mencatat bahwa perempuan sudah diperbincangkan jauh sebelum al-Qur'an diturunkan. Misalnya Yunani yang terkenal dngan filsafatnya, mereka tidak banyak berbincang tentang hak dan kewajiban seorang perempuan. Di lingkungan elit, mereka ditempatkan di istanaistana kerajaan, namun dikalangan bawah, mereka diperjualbelikan, di sisi lain yang berkeluarga sepenuhnya berada dalam genggaman suaminya. Dikalangan bangsa Romawi, perempuan sepenuhnya berada dalam kekuasaan sang ayah, namun setelah berumahtnagga kekuasaan tersebut berpindah ke tangan suami, yang meliputi: menjual, membunuh, menganiaya, dan mengusir (Shihab, 1996).

Yang lebih buruk dari Yunani dan Romawi adalah peradaban Hindu dan Cina, dimana hak hidup perempuan yang bersuami harus berakhir ketika suaminya mati. Ia harus dibakar secara hidup-hidup pada saat pembakaran mayat suami.

Lain lagi dalam ajaran Yahudi, martabat perempuan tidak ada bedanya dengan seorang pembantu. Jika ia tidak mempunyai saudara laki-laki maka ia berhak dijual oleh ayahnya. Ajaran ini menganggap bahwa perempuan merupakan sumber laknat, karena dia sebagai penyebab Adam terusir dari surga.

Sedangkan dalam ajaran orang Nasrani, perempuan merupakan senjata Iblis untuk menyesatkan manusia. Bahkan pada abab ke-5 Masehi pernah diadakan suatu konsili yang membicarakan apakah peerempuan memiliki ruh yang suci atau tidak, dan kesimpulannya bahwa perempuan tidak memiliki ruh yang suci. Di tempat lain ditemukan bahwa perempun diciptakan hanya untuk melayani laki-laki (Shihab, 1996).

Dalam fakta sejarah ditemuka, bahwa sebelum datangnya Islam kondisi perempuan memang sangat suram. Sejarah menjadi saksi bagaimana perempuan yang melahirkan manusia justru malah dihinakan, sehingga mereka tidak menjadi manusia yang bermartabat serta derajatnya turun menjadi budak. Mereka justru dipaksa harus mengabdi kepada suami yang dengan seenaknya mempertahankan atau menceraikan ('Abdullah, 1985).

Situasi dan kondisi di atas ternyata tidak sejalan dengan apa yang diajarkan al-Qur'an. Namun disisi lain ternyata masih ada para tokoh yang masih terpengaruhi oleh keadaan seperti di atas dalam 
memahami sombol petunjuk al-Qur'an. Bahkan kaum perempuan sampai saat ini masih menempati posisi kedua dalam kehidupan berbangsa dan bernegara, kecuali pada kurun Nabi saw. dan Khulafa al-Rasyidin (Shihab, 2007). Yang lebih ironis, di jaman modern ini masih terasa pandangan yang melecehkan perempuan (Nasrulloh, Mainna, Kuswana, \& Shodiqin, 2017). Selama 32 tahun pemerintahan dipimpin Orde Baru, kaum perempuan ditempatkan sebagai posisi kedua dalam kehidupan dan mereka masih terpinggirkan dari kaum laki-laki. Mereka pada umumnya hanya dilihat sebagai pajangan, pelengkap penderitaan, dan penghias ruangan laki-laki. Tidak ada ruang bagi perempuan dalam bidang politik, dunia politik hanya milik laki-laki semata. Kaum perempuan hanya penjaga gawang moral, bagaimana menjadi ibu yang baik, istri yang baik, istri pegawai yang baik, dan mengurusi orang miskin, anak yatim, dan para jompo. Padahal tantangan berat yang dihadapi perempuan paling tidak ada dua pokok: (1) tantangan rumah tangga (internal), perempuan dituntut harus menjadi orang yang feminim, lembut, perhatian, kasih sayang, dan cinta pada suami dan anak; (2) tantangan diluar rumah tangga (eksternal), mereka dituntut harus bersikap maskulin, karena tuntutan zaman yang semakin terbuka (Sawali, 2007).

Padahal dalam sudut pandang al-Qur'an, perempuan merupakan salah satu dari dua jenis jender yang diakui dan berkedudukan terhormat. Mereka memiliki hak sebagaimana kaum laki-laki. Yang membedakannya dengan laki-laki hanya dari sudut eksistensinya saja.

Dalam al-Qur'an terdapat berbagai symbol yang menunjukan makna perempuan, seperti kata zauj, imraah, ummi, Ratu Saba pada kisah Sulaiman, dan Maryam Ibu ‘Isa. Meskipun symbol perempuan dalam al-Qur' an hanya sebagai pemeran pembantu, namun mereka memainkan perenan yang sesuai dengan amanat yang diembannya, dan pada sisi lain mereka memperlihatkan karakteristik keperempuanannya.

Simbol perempuan dalam kisah al-Qur'an sangat menarik untuk dikaji dengan menggunakan pendekatan semiotika, terutama semiotika Roland Barthes, dalam rangka pencarian makna yang utuh terkait proses pemberdayaan perempuan. Al-Qur'an yang merupakan petunjuk bagi manusia sarat dengan symbol-simbol normative yang dapat menepis kekerasan, beban ganda, dan marginalisasi perempuan.

Dalam semiotika Roland Barthes, bahwa hubungan antara petanda dan penanda tidak terbentuk dengan sendirinya melainkan bersifat arbitrer, yaitu merupakan hubungan yang terbentuk berdasarkan konvensi (Kuswana, Qomaruzzaman, \& Mahatma, 2020). Oleh sebab itu, pada dasarnya penanda meberi ruang terhadap berbagai petanda atau makna. Menurut Barthes, bahwa setiap tanda yang digunakan dalam sistem pertandaan, secara semiotika structural harus bersandar pada struktur dalam sistem langue. Dengan demikin, pada tahapan ini Barthes masih memegang kaidah-kaidah strukturalisme, tapi dia tidak terpaku pada diadik signifier-signified-nya Saussure. Baginya, signifikansi merupakan peroses memadukan penanda dan petanda yang menghasilkan tanda. Signifikansi tidak memadukan etnis-etnis yang unilateral, tidak pula memadukan dua term semata, sebab petanda dan penanda merupakan term-term dari relasi. Ia lebih mengembangkan konsep pemaknaan konotasi dan tidak berhenti pada makna denotative (Rusmana, 2014).

Sebagai contoh dari aplikasi teori Barthes dalam al-Qur'an adalah pengungkapan "ideology" dalam lafaz tijarah (perniagan). Seperti yang terdapat dalam QS. al-Shaff (61) ayat 10-11 yang artinya:

Hai orang-orang yang beriman, sukakah kamu aku tunjukkan suatu perniagaan yang dapat menyelamatkanmu dari azab yang pedih? (yaitu) kamu beriman kepada Allah dan RasulNya dan berjihad di jalan Allah dengan harta dan jiwamu. Itulah yang lebih baik bagimu, jika kamu mengetahui.

Lafaz tijarah yang digunakan al-Qur'an merupakan symbol dari sesuatu yang menguntungkan dan menyelamatkan, yaitu berupa iman kepada Alla swt. dan Rasul-Nya serta berjihad di jalan Allah swt. dengan harta dan jiwa. Seolah-olah tidak ada profesi lain yang menguntungkan dan lebih baik dari itu. Ternyata rahasianya dapat kita lihat dari sejarah bangsa Arab yang sejak dulu merupakan orang-orang yang mata pencahariannya berniaga, selain bercocok tanam. Fakta sejarah menunjukan bahwa orng-orang kaya dari mereka merupakan orang yang berniaga. Oleh sebab itu, dalam benak mereka pada saat itu, jika ingin kaya dan selamat dari kemiskinan maka harus berniaga. Ketika Islam 
datang, maka kata "berniaga" yang merupakan symbol dari transaksi komoditi (barang) dan keuntungan materi (uang), dirubah referensinya pada komoditi spiritual dan immaterial, yaitu keimanan kepada Allah swt. dan Rasul-Nya; dan pada komoditi material, yaitu berjihad dengan harta dan jiwa. Keuntungan berniaga seperti itu melebihi keuntungan berniaga yang bersifat materi, yaitu dapat selamat dari azab yang pedih. Dengan demikian, berniaga dalam ayat di atas mengandung ideology materialism-spiritualistik (Taufiq, 2016).

Penelitian symbol perempuan dalam al-Qur'an, dengan menggunakan semiotika Barthes, merupakan penelitian yang mengarah pada literature dan berbagai tafsir. Oleh sebab itu, metode yang digunakan pada penelitian ini adalah metode deskriptif, yaitu sebuah metode penelitian yang berupaya menginterpretasikan serta mendeskripsikan sesuatu, baik kondisi maupun hubungan yang ada, pendapat yang berkembang atau bahkan proses yang sedang berlangsung (Sukmadinata, 2019). Mengacu pada metode tersebut, pada penelitian ini penulis akan mengungkapkan pendapat para ahli yang telah melakukan penelitian dan telah memberikan pandangan terkait symbol perempuan yang terdapat dalam al-Qur'an dan latar belakang sejarah yang terkait dengan symbol tersebut. Selain itu penulis akan menggunakan pendekatan tafsir dalam melakukan penelitian ini, mengingat penelitian ini merupakan penelitian terhadap kalimat-kalimat al-Qur'an.

\section{Hasil Penelitian}

\section{Semiotika}

Semiotik merupakan salah satu terma yang berasal dari kata Yunani semeion,yang memiliki arti tanda, atau berasal dari kata semeiotikos, yang artinya teori tanda. Menurut Paul Colbey, sebagaimana dikutip oleh Dadan Rusmana, bahwa kata semiotika juga berasal dari kata Yunani same, yang artinya penafsir tanda. Semiotika merupakan cabang ilmu yang sudah dikenal sejak masa Yunani, namun cabang ilmu ini baru berkembang sekitar tahun 1900-san. Bahkan istilah semiotika baru digunakan oleh Lambert, seorang filsuf dari Jerman, pada abad ke-18 (Rusmana, 2014).

Para ahli semiotika memberikan berbagai definisi yang berbeda, ada yang mengatakan logika, yang artinya dokrin tanda yang "pura-pura penting", ada lagi yang mengatakan ilmu yang mengkaji tanda-tanda dalam kehidupan, segla sesuatu yang dapat dianggap sebagai tanda, ilmu tentang bentukbentuk, dan banyak lagi definisi yang lainnya. Namun dari berbagai definisi yang diberikan para ahli, sebetulnya mereka sepakat bahwa semiotika adalah ilmu yang mengkaji tanda. Dalam Kamus Besar Bahasa Indonesia, tanda adalah gejala, bukti, pengenal, lambang, petunjuk, dan yang menjadi alamat atau yang menyatakan sesuatu.

Sementara menurut Berger, sebagaimana dikutip oleh Wildan Taufiq, tanda merupakan sesuatu yang berdiri sendiri pada sesuatu yang lainnya atau menambah dimensi yang berbeda pada sesuatu dengan memakai apa pun yang dapat digunakan untuk memberikan arti pada sesuatu yang lainnya. Menurut Berger, dintara berbagai tanda yang paling penting adalah bahasa (kata-kata). Misalnya kata "pohon" artinya berbeda dengan yang dimaksud tumbuhan yang menjalar yang hanya memiliki batang tunggal tanpa memiliki cabang satu pun di bagian bawahnya. "Kata" dipakai sebagai sebuah tanda dari idea tau konsep. Yang harus diingat adalah tujuan komunikasi, yaitu tanda merupakan sesuatu yang bermakna (Taufiq, 2016).

Perbincangan mengenai semiotika dalam khazanah keilmuan secara signifikan dimulai pada abad ke-20, tepatnya ketika logosentrisme menempati posisi yang sangat penting dalam ilmu filsafat. Arus ini digulirkan oleh dua tokoh yang merupakan founding father dalam bidang semiotika, yaitu Ferdinand de Saussure dan Charles Sanders Peirce. Kedua orang ini memang hidup sezaman, namun keduanya tidak saling mengenal, mereka berada dalam tempat yang berbeda dan berjauhan. Dimana Saussure berada di Eropa, sedangkan Peirce berada di Amerika. Namun arus semiotika yang mereka hembuskan hampir bersamaan, meskipun memiliki landasan semiotika yang berbeda hingga keduanya melahirkan konsep yang berbeda pula. Karena memiliki latar belakang disiplin ilmu yang berbeda, dimana Peirce merupakan pakar linguistic dan logika, sementara Saussure sebagai ahli linguistic modern, maka terdapat perbedaan mendasar dalam penerapan konsep semiotika sekarang ini. 
Dengan adanya dua tokoh semiotika di atas, maka istilah yang digunakan pun berbeda, dimana orang-orang Amerika menggunakan istilah semiotika dan orang-orang Eropa menggunkan istilah semiologi. Perbedaan dua istilah tersebut dalam menyebut setudi tanda, tidak memiliki perbedaan yang signifikan, kecuali dalam persoalan orientasi yang berbeda (Rosyad, 2007). Menurut Alex Sobur, seperti yang dikutip oleh Dadan Rusmana, kedua istilah ini merupakan dialektiaka antara dua kubu semiotika modern, yaitu kubunya Ferdinand de Saussure dan kubunya Charles Shanders Peirce. Keduanya menyiratkan variasi-variasi penting dalam penerapan konsep semiotika tersebut. Variasi tersebut bukan hanya masalah penggunaan istilah saja, tetapi menyangkut persoalan paradigma pemikiran tentang tanda, ranah semiotik, metode, dan proses pengaplikasian (Rahman et al., 2020). Dalam bidang penerapan semiotik dari konsep linguistik dan konsep psikologi sosial sebagian besar pakar semiotic berkiblak pada Saussure, sementara dalam bidang penerapan semiotika dari konsep filsafat, logika dan pragmatisme berkiblat pada Peirce (Taufiq, 2016).

Pengembangan kajian semiotika yang dirintis oleh kedua tokoh di atas, sangat penting untuk dikembangkan pada ayat-ayat al-Qur'an. Dengan alasan bahwa masih jarang yang menggali al-Qur'an dengan pendekatan ini dan untuk mengungkap al-Qur'an dengan versi al-Qur'an itu sendiri, yaitu identitas al-Qur'an yang bebas dari bias ideologi, yang dalam bahasa Barthes disebut expression (E) dan content (C) (Sanusi, 2011).

\section{Roland Barthes dan Teori Semiotikanya}

\section{Biografi Roland Barthes}

Rolan Barthes merupakan orang yang lahir dari keluarga menengah yang beragama Protestan. Ia lahir di kota kecil Cherbourg dekat pantai Atlantik disebelah barat daya Prancis dan Paris pada tahun 1915. Ia tumbuh dan besar di Bayonne dalam asuhan ibu dan kakek-neneknya, karena ayahnya seorang tentara yang gugur di medan pertempuran saat ia baru usia satu tahun.

Ia hobi bermain piano dan mendapatkan bimbingan dari bibinya yang ngerti main piano. Kehidupannya dilatari dengan budaya borjuis dan sering mendengarkan para nyonya bergosip ketika mereka minum teh. Ketika ia berusia Sembilan tahun ia pindah ke Prancis mengikuti ibunya yang bekerja sebagai penjilid buku yang berupah kecil.

Pada tahun 1934, Barthes terobsesi masuk Ecole Normale Superiure, namun keinginannya tidak terlaksana karena terhambat penyakit TBC yang ia derita sebelumnya, yang mengakibatkan ia harus berobat kePyrences (Taufiq, 2016). Selama ia melakukan pengobatan, banyak hal yang ia pelajari, dari mulai mempelajari Marxisme sampai Eksistensialisme Sartre. Itulah yang melatar belakangi intelektualisme Barthes awal lebih cenderung Marxian dan Sartrean. Setelah satu tahun berobat, Barthes masuk Universitas Sorbone dan mengambil jurusan bahasa dan sastrs Prancis serta studi klasik (Latin, Romawi, dan Yunani). Bahkan ia pun aktif bermain teater dan drama-drama klasik bersama teman-temannya (Rusmana, 2014).

Pada tahun 1948, Barthes menjadi pengajar bahasa dan sastra Prancis di luarnegeri, yaitu di Bukarest (Rumania) kemudian di Mesir yang merupakan tempat dia belajar Linguistik Modern dari A. J. Greimas sebagai koleganya. Sekembalinya ke Prancis, ia bekerja di Centre National de Recherche Scientifikue (Pusat Nasional Untuk Penelitian Ilmiah) dan melahirkan artikel tentang sastra (Rahman, 2016). Pada tahun 1952 ia mendapatkan beasiswa untuk mengerjakan sebuah tesis leksikologi, yaitu sebuah kamus sosial abad XIX. Pengerjaan tesisnya mengalami kemajuan, namun sebelum proyek itu selesai ia malah menerbitkan dua kritik sastra, yaitu Le Degree Zero de I'ecriture (Nol Drajat di Bidang Menulis; 1953) dan Micheletpar Lui Meme (1954). Pada buku pertama ia mengkritik kebudayaan borjuis, yang dalam hal ini ia sejalan dengan Sartre dan Marxis Prancis saat itu.

Barthes memiliki pemikiran yang kreatif, dinamis dan plural. Pemikirannya dapat dikatakan anti kemapanan (ikonoklas) serta menentang segala macam kesatuan dan kontinuitas, bahkan sebliknya ia malah menekankan diskontinuitas dan pluralitas (Rahman, 2010). Pada tahun 1955 ia malah kehilangan beasiswanya sebelum ia menyelesaikan karya leksikologinya. Akhirnya ia bekerja di sebuah penerbitan dan tidak hentinya ia menulis banyak artikel, termasuk studi tentang budaya kontemporer yang 
kemudian dipublikasikan dengan judul Mythologis (1957), buku ini banyak menganalisis berbagai data cultural yang dikenal umum (seperti mobil Citroen DS, balap speda Tour de France, sabun mandi, reklame di surat kabar dan lain-lain) sebagai gejala masyarakat borjuis dan kemudian ia memperlihatkan ideologisnya (Rusmana, 2014; Taufiq, 2016).

Pada saat ia membaca buku Ferdinand de Saussure, yang berjudul Coure de Linguistic Generale, pada tahun 1956, ia menyadari adanya kemungkinan penerapan semiologi di luar linguistic. Namun pendapatnya berbeda dengan pendapat Saussure yang merupakan idolanya, dimana Barthes beranggapan bahwa semiologi harus menjadi bagian dari linguistic, bukan sebaliknya. Ia sependapat dengan linguis prancis yang berasal dari Lebanon bernama E. Benveniste yang menekankan bahwa sekelompok tanda bisa bermakana jika terbahasakan. Oleh sebab itu, bahasa merupakan pemilik peran penting dalam semua sistem tanda yang lain.

Pada tahun 1960, ia mendapatkan sebuah posisi di Ecole Pratique de Hautes Etudes, saat beasiswanya hampir habis, yaitu sebagai dosen regular di sana. Pengabdian yang dilakukannya akhirnya membuahkan hasil, hingga pada tahun 1976 ia diangkat sebagai professor untuk semiologi literer di College de France. Masa ini merupakan masa pergulatannya dengan strukturalisme, terutma semiologi. Sehingga pada tahun1964 ia mengeluarkan dua karya yang berkaitan dengan semiologi, yaitu Elements de Semiologi (Beberapa Unsur Semiologi) dan Sur Racine (Tentang Racine). Karya Elements de Semiologi akhirnya menjadikan Barthes sebagai salah seorang bapak semiologi structural.

Karya berikutnya yang ditulis Barthes adalah Syisteme de Ia Mode (Sistem Mode: 1967) yang dihasilkan setelah ia mendapatkan beaasiswa pada tahun 1955. Buku ini merupakan percobaannya menerapkan metode analisis structural terhadap mode pakaian wanita dengan menyelidiki artikelartikel yang memuat mode pakaian wanita dalam dua majalah dari tahun 1958/1959. Ia menemukan bahwa di belakang mode pakaian wanita yang tampak sepele dan kebetulan itu ternyata ada suatu sistem (Rusmana, 2014; Taufiq, 2016).

\section{Terori Semiologi Roland Barthes}

Pada tahun 1956 Barthes membaca karya Saussure, sejak itu ia kemudian menyadari kemungkinan-kemungkinan penerapan semiologi di bidang lain. Namun pandangannya berbeda dengan Saussure, diman ia beranggapan bahwa semiologi termaasuk linguistic bukan sebaliknya. Oleh sebab itu, semiologi Barthes merupakan pengembangan dari semiologi Saussure. Dalam hal ini, usaha Barthes dalam mengembangkan semiologi selaras dengan cita-cita Saussure, yaitu bagi seorang ahli bahasa harus menjadikan kajian struktur bahasa sebagai fokus utama, yang kemudian harus menghubungkannya dengan objek lain yang ada di luar bahasa sebagai penerapannya.

Menurut Barthes, semiologi Saussure merupakan sistem semiologi tahap pertama yang perlu dikembangkan tahap selanjutnya yang menjadi tahap kedua. Menurutnya tahap pertama disebut sistem linguistik dan tahap yang kedua disebut sistem mitis (mitos). Untuk menghasilkan sistem mitis maka harus menjadiakan sistem tanda tingkat pertama sebagai Signifier, dan Signified-nya diciptakan oleh pembaca mitis (Taufiq, 2016). Dalam pandangan Barthes, mitos merupakan sistem komunikasi atau pesan yang fungsinya adalah mengungkap dan memberi pembenaran terhadap nilai-nilai dominan yang berlaku pada periode tertentu. Selain tiu mitos juga selalu ditmpilkan dalam bentuk wacana (Wibisono, 2020). Oleh sebab itu, maka yang terpenting dari suatu pesan, selain isi adalah cara bagaimnan pesan itu diungkapkan, dalam hal ini mitos dapat diartikan sebagai model ujaran. Dalam rumusan Barthes yang lain, mitos adalah pengodean makna dan nilai-nilai sosial sebagai sesuatu yang dianggap alamiah. Dengan demikian, Barthes menempatkan mitos sebagai makna terdalam dan bersifat konvensional. Dalam pandangan Barthes, semiotika itu dikembangkan menjadi dua tingkatan pertandaan, yaitu denotasi dan konotasi (Sudarto, Senduk, \& Rembang, 2015).

Berdasarkan teori tersebut, segala realitas yang ada di dunia dapat dijadikan mitos atau model ujaran sebuah gagasan, karena mitos diasumsikan sebagai sistem penanda yang dibangun berdasarkan tiga hal, yaitu penanda (signifier), petanda (signified), dan tanda (sign). Sistem penandaan dalam sebuah mitos merupakan rantai semiologis yang ada sebelumnya. Pada tingkatan mitos, tanda dalam sistem primer merupakan penanda baru, melalui kesatuannya dengan penanda baru tersebut maka terbentuk 
lah tanda. Misalkan kita lihat dalam seseorang yang menggunakan jilbab. Pada tingkatan semiotic, jilbab sebagai tanda kesopanan dan ketertutupan tubuh. Selanjutnya, pada tingkatan ideologis kesopanan merupakan tanda dari kesalehan, kepatuahan kepada Tuhan, dan sebagainya. Oleh sebab itu, jika seorang muslimah memakai jilbab, maka ia tidak hanya berpikir fungsi jilbab sebagai penutup tubuh, tetapi ada gagasan lain yang lebih tinggi, seperti konsep kesalehan dan ketaatan terhadap Tuhan (Rusmana, 2014).

Teori lain yang dikenalkan oleh Barthes adalah the death of author (kematian sang pengarang). Barthes tidak mengikut sertakan pengarang dalam menentukan sebuah makna, hal ini sama seperti para kaum strukturalisme lainya. Mereka meyakinkan para pembaca bahwa pengarang sudah mati. Dengan kata lain, Barthes sepakat dengan para strukturalisme lainnya bahwa penulis telah mati ketika teks itu tercipta, yang kemudian Barthes merayakan pluralitas dan mengumumkan bahwa penulis telah mati. Pernyataan tersebut menjadi hal yang sangat penting dalam pemikiran Barthes yang terkait dengan martabat sebuah tulisan. Kata penulis tidak hanya mengacu pada sebuah pengertian penulis, melainkan sebagai kompetisi dan wewenang para pihak atau lembaga dalam menentukan makna final atau makna yang paling abash dari sebuah teks.

Hal yang dilakukan Barthes terhadap teks memberikan peluang besar terhadap interpretasi baru yang dapat memberikan kebaruan makna pada teks tersebut. Pada permasalahan teks sastra misalnya, ia telah memberikan sumbangan kritik sastra. Sedangkan terhadap teks keagamaan ia memberikan cara lain untuk memahaminya dan memberikan keleluasaan makna terhadap teks tersebut. Teks tersebut akan selalu bersinggungan dengan realitas aktual. Namun persoalan yang muncul kemudian adalah Barthes tidak bertanggung jawab secara filosofis terhadap klaim yang dibuatnya (Rosyad, Mubarok, Rahman, \& Huriani, 2021). Apakah teks filsafat sama dengan teks agama atau berbeda? Memang dari sudut linguistic keduanya memiliki kesamaan, karena keduanya sama-sama memerlukan bahasa sebagai alat uantuk mengomunikasikan sesuatu, keduanya sama-sama mematuhi praturan kebahasaan. Namun teks keagamaan harus disikapi secara hati-hati karena menyangkut keimanan suatu kaum yang memiliki implikasi yang berbeda dengan teks sastra.

Semiotika Barthes lainnya adalah persoalan Analisis Naratif Structural, yaitu, analisis tekstual yang dapat digunakan untuk menganalisis berbagai bentuk naskah baik novel maupun Kitab Injil. Secara sederhananya analisis ini disebut semiologi teks, karena memfokuskan diri pada naskah. Menurutnya teks harus diperlakukan secara netral, yaitu merelativisasi hubungan yang ada antara penulis (writer), pembaca (reader), dan pengamat (observer), karena teks bukan hanya untaikan katakata yang siap melepaskan makna teologis (pesan dari pencipta), melainkan juga berasal dari ruang multi dimensi yang berada dalam berbagai tulisan. Namun yang menjadi persoalan tidak adanya mesin pembaca makna, yang ada hanya mesin penerjemah yang hanya mampu mentransformasikan makna denotatif saja, tidak mampu membongkar makna-makna kedua atau makna konotatif.

Berdasarkan hal di atas, menurut Barthes, karya atau teks hanyalah sebuah kontruksi. Jika kita ingin mengetahui maknanya maka harus melakukan rekontruksi dari bahan-bahan yang ada yaitu teks, dengan cara memenggal teks terlebih dahulu menjadi beberapa satuan bacaan atau leksia. Apabila leksia diisolasikan maka akan berdamapak atau berfungsi yang khas dibanding potongan kata lain yang ada disekitarnya (Rusmana, 2014).

Tori Barthes selanjutnya yang sangat penting dalam memaknai sebuah teks adalah tentang perbedan makna Denotasi (makna primer) dan makna Konotasi (makna kedua). Menurut Barthes, denotasi merupakan sebuah tanda yang penandanya memiliki tingkat konvensi atau kesepakatan yang tinggi dan sebaliknya memiliki tingkat keterbukaan yang rendah. Dalam kata lain, denitasi merupakan tnda yang menghasilkan makna eksplisit atau merupakan makna harfiah, dan makna yang sesungguhnya. Bagi Roland Barthes, denotasi merupakan signifikansi tingkat pertama yang harus disingkirkan dan ditolak. Baginya, makna denitasi tidak ada, yang ada hanya lah makna konotasi.

Sementara yang dimaksud dengan konotasi adalah tanda yang penandanya memiliki keterbukaan makna. Artinya, makna yang dapat menghasilkan makna kedua yang bersifat implicit. Biasanya konotasi mengacu pada makna yang menempel pada kata, tetapi dalam Semiologi Barthes, konotasi tidak hanya memiliki makna tambahan melainkan juga mengandung kedua bagian tanda denotatif. 
Menurut Barthes, perkembangan tanda selalu mengikuti dua sistem, yaitu sistem primer dan sistem sekunder. Sistem primer (lapisan pertama), yaitu ketika tanda diproduksi dan dipahami pada taraf pemaknaan pertama. Sistem ini disebut pemaknaan language atau denotasi. Sedangkan sistem sekunder adalah ketika tanda mengembangkan ekspresinya serta memperoleh keluasan konteks. Sistem kedua ini dinamakan sistem metabahasa atau sistem konotasi. Kedua sistem tersebut berawal dari teori diadik Saussure yang dikembangkan oleh Barthes menjadi expression (E) mengacu pada penanda, content (C) mengacu pada petanda, dan dintara keduanya ada relation (R). Sebagai contohnya kita ambil kata "meja hijau". Pada lapisan pertama, kata ini bermakna meja yang berwarna hijau. Dalam kehidupan sosial budaya, meja hijau berarti pengadilan.

Untuk contoh yang lebih jelasnya dapat kita lihat pada contoh Bendera Merah Putih bagi masyarakat Indonesia. Konsep "Bendera Merah Putih" (E) dan "lambang bendera bangsa Indonesia" $(C)$, berrelasi $(R)$ yang berrelasi pada sisitem primernya dan dapat berkembang pada relasi (R) sekundernya karena ada perluasan content (C), misalnya menjadi lambang nasionalisme, lambang keberanian dan kesucian (Rusmana, 2014).

Contoh lain dari teori Barthes dapat dilihat pada konteks tijarah dalam al-Qur' an yang merupakan symbol dari keuntukan. Seperti yang terdapat dalam QS. al-Shaff (61) ayat 10-11 yang artinya:

Hai orang-orang yang beriman, sukakah kamu aku tunjukkan suatu perniagaan yang dapat menyelamatkanmu dari azab yang pedih? (yaitu) kamu beriman kepada Allah dan RasulNya dan berjihad di jalan Allah dengan harta dan jiwamu. Itulah yang lebih baik bagimu, jika kamu mengetahui.

Lafaz tijarah yang digunakan al-Qur'an merupakan symbol dari sesuatu yang menguntungkan dan menyelamatkan, yaitu berupa iman kepada Allah swt. dan Rasul-Nya serta berjihad di jalan Allah swt. dengan harta dan jiwa. Seolah-olah tidak ada profesi lain yang menguntungkan dan lebih baik dari itu. Ternyata rahasianya dapat kita lihat dari sejarah bangsa Arab yang sejak dulu merupakan orang-orang yang mata pencahariannya berniaga, selain bercocok tanam. Fakta sejarah menunjukan bahwa orng-orang kaya dari mereka merupakan orang yang berniaga. Oleh sebab itu, dalam benak mereka pada saat itu, jika ingin kaya dan selamat dari kemiskinan maka harus berniaga. Ketika Islam datang, maka kata "berniaga" yang merupakan symbol dari transaksi komoditi (barang) dan keuntungan materi (uang), dirubah referensinya pada komoditi spiritual dan immaterial, yaitu keimanan kepada Allah swt. dan Rasul-Nya; dan pada komoditi material, yaitu berjihad dengan harta dan jiwa. Keuntungan berniaga seperti itu melebihi keuntungan berniaga yang bersifat materi, yaitu dapat selamat dari azab yang pedih. Dengan demikian, berniaga dalam ayat di atas mengandung ideologi materialism-spiritualistik (Taufiq, 2016).

\section{Simbol Perempuan dalam Al-qur'an}

Al-Qur'an menjelaskan tentang perempuan dengan istilah yang sangat banyak. Dari sekian banyak istilah yang digunakan al-Qur'an untuk mengidentifikasi perbedaan perempuan dengan lakilaki memang memiliki ragam makna dan kedudukan. Dalam semiotika Barthes, perkembangan tanda selalu mengikuti dua sistem, yaitu sistem primer dan sistem sekunder. Sistem primer (lapisan pertama), yaitu ketika tanda diproduksi dan dipahami pada taraf pemaknaan pertama. Sistem ini disebut pemaknaan language atau denotasi. Sedangkan sistem sekunder adalah ketika tanda mengembangkan ekspresinya serta memperoleh keluasan konteks. Sistem kedua ini dinamakan sistem metabahasa atau sistem konotasi. Dalam rumusan Barthes yang lainnya ada yang disebut mitis (mitos). Menurutnya tahap pertama disebut sistem linguistik dan tahap yang kedua disebut sistem mitis (mitos). Untuk menghasilkan sistem mitis maka harus menjadiakan sistem tanda tingkat pertama sebagai Signifier, dan Signified-nya diciptakan oleh pembaca mitis. Mitos adalah pengodean makna dan nilai-nilai sosial sebagai sesuatu yang dianggap alamiah. Dengan demikian, Barthes menempatkan mitos sebagai makna terdalam dan bersifat konvensional. Berdasarkan hal tersebut, maka penulis akan meneliti Simbol perempuan dalam al-Qur'an melalui tahap pertama dan tahap kedua, agar dapat 
mengetahui nilai-nilai sosial yang ada dibalik symbol perempuan. Ada berbagai symbol perempuan dalam al-Qur'an, namun yang akan diteliti oleh penulis hanya sebagiannya saja, diantaranya:

a. Perempuan sebagai zauj

Dalam al-Qur'an, perempuan termasuk dalam kategori zauj atau pasangan, sebagaimana dijelaskan dalam QS. al-Najm (53): 45-46 yang artinya:

"dan bahwasanya Dialah yang menciptakan berpasang-pasangan pria dan wanita. Dari air mani, apabila dipancarkan."

Ayat lainnya yang mengisyaratkan perempuan sebagai zauj adalah QS. al-Zariyat (51): 49:

Artinya:

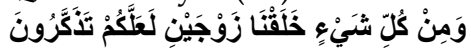

"Dan segala sesuatu Kami ciptakan berpasang-pasangan supaya kamu mengingat kebesaran Allah."

Kedua ayat di atas member isyarat bahwa pada dasarnya laki-laki dan perempuan itu memiliki kesamaan dan kesetaraan, baik dari asal kejadian manusia, yaitu sperma, maupun dari tujuan penciptaan, yaitu untuk mengingat Allah swt.

Symbol perempuan sebagai zauj dalam al-Qur'an diperankan oleh Zauj Adam (pasangan Nabi Adam) yang disebutkan dalam al-Qur'an sebanyak lima kali dengan lafaz zaujuka. Tiga lafaz zaujuka merujuk kepada pasangan Adam, yaitu istri Nabi Adam. Istri Adam ini diceritakan sebagai istri yang diperintahkan untuk menemani Adam di surge dan makan buah-buahan yang melimpah dengan sebebas-bebasnya, tetapi jangan sampai mendekati satu pohon yang terlarang. Hal ini tercatat dalam QS. al-A'raf (7): 19 dan QS. al-Baqarah (2): 35. Dalam Surat Taha (20) ayat 117 dijelaskan bahwa Adam telah diperingati oleh Allah swt. bahwa Iblis merupakan musuhnya dan musuh istrinya, jika Iblis sampai berhasil mengusir Adam dan istrinya dari surge, maka mereka berdua akan mengalami kesengsaraan atau mereka harus bekerja keras. Di sisi lain Setan selalu menggoda Adam dan membisikan pikiran jahatnya tentang pohon keabadian dan kerajaan yang tidak akan binasa, segaimana dijelaskan dalam ayat 120 Surat Taha. Namun Adam tidak menaati perintah Allah swt. dengan memakan buah tersebut, dan akhirnya tersesat, segagaimana dijelaskan pada ayat selanjutnya yaitu ayat 121 dari QS. Taha.

Dalam surat yang lainnya diceritakan, ternyata ada keterlibatan perempuan dalam pembangkangan dan taubatnya Adam, sebagaimana yang terdapat dalam QS. al-A'raf ayat 20 sampai 22: "Maka syaitan membisikkan pikiran jahat kepada keduanya untuk menampakkan kepada keduanya apa yang tertutup dari mereka yaitu auratnya dan syaitan berkata: "Tuhan kamu tidak melarangmu dan mendekati pohon ini, melainkan supaya kamu berdua tidak menjadi malaikat atau tidak menjadi orang-orang yang kekal (dalam surga). Dan dia (syaitan) bersumpah kepada keduanya. "Sesungguhnya saya adalah termasuk orang yang memberi nasehat kepada kamu berdua", maka syaitan membujuk keduanya (untuk memakan buah itu) dengan tipu daya. Tatkala keduanya telah merasai buah kayu itu, nampaklah bagi keduanya aurat-auratnya, dan mulailah keduanya menutupinya dengan daun-daun surga. Kemudian Tuhan mereka menyeru mereka: "Bukankah Aku telah melarang kamu berdua dari pohon kayu itu dan Aku katakan kepadamu: "Sesungguhnya syaitan itu adalah musuh yang nyata bagi kamu berdua? Dalam Surat al-Baqarah ayat 36 dikatakan "Lalu Iblis menggelincirkan keduanya dari surge". Dengan demikian mereka berdua tingal di bumi untuk sementara waktu, dan sebagian dari mereka menjadi musuh bagi yang lainnya. Itu lah yang dijelaskan dalam QS. al-Baqarah ayat 36. Dalam Surat Taha ayat 122 diceritakan bahwa Allah swt. menerima taubat Adam dan memberinya petunjuk.

Sebagai pembaca mitos dalam teorinya Barthes, maka kisah di atas dapat dijadikan sebagai Signifier, sedangkan Signified-nya dapat diciptakan oleh pembaca mitos itu sendiri (Taufiq, 2016).

Berdasarkan teori tersebut, yang dapat diperoleh dari kisah di atas, bahwa dalam sistem linguistic (I) kata Adam dan zauj (pasangannya) sebagai signifier, sedangkan signified-nya Adam dan zauj itu sendiri. Sedangkan pada sistem mitos (II), signifier-nya adalah kata Adam zauj dan Adam zauj itu sendiri beserta seluruh kejadian yang menyertainya. Adapun signified-nya perempuan dan laki-laki memiliki kedudukan yang sama, sebagaimana dalam kisah adam tersebut. Mereka berdua mendapatka perlakuan yang sama, baik ketika mereka berdua diperintahkan diam di surga, 
diperbolehkan bersenang-senang dengan makan apa saja kecuali pohon larangan, keduanya digoda, mendapat pringatan keras akibat melangar, diprintahkan turun ke bumi, maupun keduanya memohon ampunan. Keduanya diperlakukan sama oleh Allah swt dengan menggunakan lafaz شئتما, yaitu Damir Musanna (kata ganti untuk berdua).

Wahbah bin Mustafa al-Zuhaili menjelakan dalam Tafsir al-Wasit, bahwa kisah Adam ini merupakan penghormatan dari Allah swt. terhadap manusia, yaitu dengan menempatkan Adam dan istrinya (Haw) di surga (Al-Zuhaili, n.d.). Dalam hal ini, semua manusia, baik laki-laki maupun perempuan, mendapatkan penghormatan dan kemulyaan yang sama dari Allah swt. dan tidak ada perbedaan diantara mereka.

b. Perempuan Sebagai Imra'ah (istri)

Perempuan sebagai istri dalam al-Qur'an diperankan oleh beberapa tokoh, seperti istri Nabu Lut, istri Nabi Ibrahim, istri Fir'aun, istri pembesar kerajaan (Imra'ah al-'Aziz) yang terdapat pada kisah Nabi Yusuf, dan istri Imran.

1. Istri Nabi Nuh dan Isrtri Nabi Lut

Kisah tentang Istri Nabi Nuh dan Isrtri Nabi Lut\{ terdapat dalam QS. al-Tahrim (66): 10 yang artinya:

Allah membuat isteri Nuh dan isteri Luth sebagai perumpamaan bagi orang-orang kafir.

Keduanya berada di bawah pengawasan dua orang hamba yang saleh di antara hamba-hamba

Kami; lalu kedua isteri itu berkhianat [1488] kepada suaminya (masing-masing), maka suaminya itu tiada dapat membantu mereka sedikitpun dari (siksa) Allah; dan dikatakan (kepada keduanya): "Masuklah ke dalam jahannam bersama orang-orang yang masuk (jahannam).

Ayat di atas menegaskan bahwa istri Nabi Nuh mrupakan perempuan yang kafir karena membangkang, durhaka, tidak setia, berbohong, dan berhianat terhadap suaminya yang merupakan Nabi Allah swt. Dan ternyata walau pun istri Nabi tidak ada jaminan untuk masuk surga, ketika ia durhaka maka Allah menetapkan tempt baginya di neraka.

Istri Nabi Nuh melakukan ibadah yang tidak sesuai dengan ajaran suaminya, ia justru malah melakukan penyembahan terhadap Matahari. Selain itu ia juga menjauhkan para perempuan di sana dari ajaran Nabi Nuh, serta ia mengejek suaminya. Dengan begitu, maka ia melakukan tiga penghianatan besar, yaitu tidak beriman kepada Allah swt., berusaha menggagalkan misi suami, dan pembangkangan terhadap suami (Nasir, 2016).

Sebagaimana halnya istri Nabi Nuh, istri Nabu Lut pun digambarkan dalam al-Qur'an sebagai istri yang banyak berbuat dosa dan mendapatkan kutukan dari Allah swt. Dalam surat al-Tahrim (66) ayat 10 misalnya, kedua perempuan ini digambarkan sebagai perempuan yang berkhianat kepada suaminya yang saleh, namun walaupun memiliki suami yang saleh, ternyata tidak menjadi jaminan untuk mendapatkan ampunan dari Allah swt. dan mereka tetap sebagai ahli neraka.

Kedua isti Nabi tersebut digambarkan oleh Allah swt. sebagai perempuan yang jahat, durhaka dan menentang Allah swt. Dengan gambaran ini agar perempuan-perempuan lain mengambil hikmah dari keduanya dalam menjauhkan diri mereka dari sifat penghianatan kepada Allah swt. Pada surat al-Tahrim (66) ayat 10 dijelaskan juga bahwa dikatakan kepada mereka "masuklah ke neraka bersama orang-orang yang masuk neraka".

2. Istri Nabi Ibrahim

Al-Qur'an menyebutkan istri Nabi Ibraham sebanyak dua kali dengan kata imra'atuhu, yaitu QS. Hud (11): 71-73 dan QS. al-Dzariyat (51): 29-30, dan dengan kata ahlahu, yaitu yang terdapat dalam QS. al-Baqarah (2): 126. Ketiga lafaz tersebut bermakna istri atau keluarga Nabi Ibrahim. Adapun ayatnya adalah sebagai berikut:

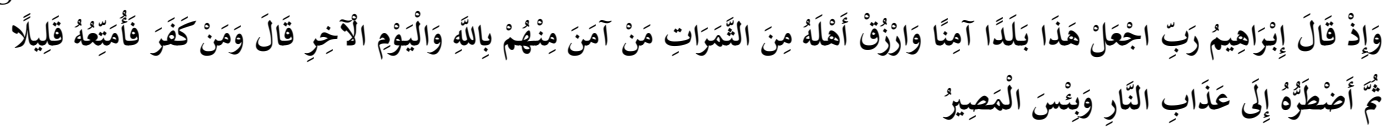

Artinya: 
Dan (ingatlah), ketika Ibrahim berdoa: "Ya Tuhanku, jadikanlah negeri ini, negeri yang aman sentosa, dan berikanlah rezki dari buah-buahan kepada penduduknya yang beriman diantara mereka kepada Allah dan hari kemudian. Allah berfirman: "Dan kepada orang yang kafirpun Aku beri kesenangan sementara, kemudian Aku paksa ia menjalani siksa neraka dan itulah seburukburuk tempat kembali.
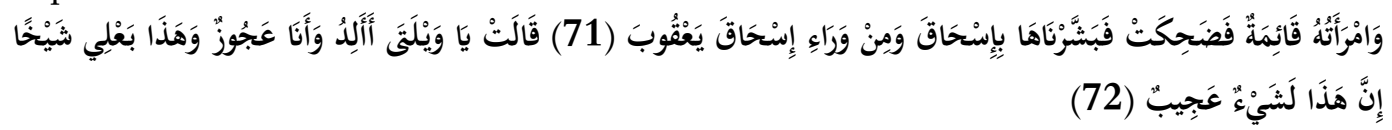

Artinya:

Dan isterinya berdiri (dibalik tirai) lalu dia tersenyum, maka Kami sampaikan kepadanya berita gembira tentang (kelahiran) Ishak dan dari Ishak (akan lahir puteranya) Ya 'qub. Isterinya berkata: "Sungguh mengherankan, apakah aku akan melahirkan anak padahal aku adalah seorang perempuan tua, dan ini suamikupun dalam keadaan yang sudah tua pula? Sesungguhnya ini benar-benar suatu yang sangat aneh."

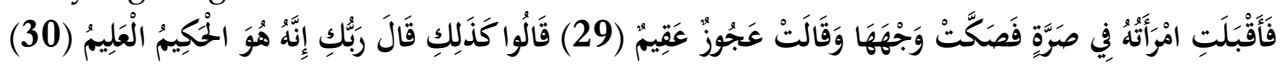

Artinya:

Kemudian isterinya datang memekik lalu menepuk mukanya sendiri seraya berkata: " (Aku adalah) seorang perempuan tua yang mandul."

Al-Qura'an mengisahkan perempuan dalam rumah tangga Nabi Ibrahim yang terdiri dari dua perempuan, yaitu istri pertama dan istri kedua. Namun dalam konteks rumahtangga yang disebutkan hanya istri pertamaya yang mandul tapi mendapatkan kabar gembira dari malaikat bahwa dia akan melahirkan seorang putra (Ishaq). Malaikat pembawa informasi tersebut adalah malaikat yang akan menuju ke kediaman Nabi Lut. Para malaikat ini termasuk tamu-tamu Nabi Ibrahim yang dimulyakan, bahkan Ibrahim membawa daging anak sapi gemuk yang dibakar sebagai hidngan untuk mereka. Namun mereka (malaikat) tidak memakannya, dan Ibrahim merasa takut. Tetapi para malaikat menenangkan Ibrahim dengan berkata "jangan takut", kemudian mereka memberi kabar gembira dengan kelahiran anak yang 'alim (Ishaq). Pada saat itu kemudian istrinya muncul dengan berteriak (heran) dan menepuk mukanya sendiri sambil berkata "aku adalah perempuan yang mandul." Dalam ayat yang lain yaitu QS. Hud ayat 69-71 dijelaskan bahwa malaikat menenangkan rasa takut Ibrahim dengan berkata bahwa mereka adalah malaikat Allah swt. yang diutus untuk kaum Lut, dan mereka memberi tahu istri Ibrihim yang ada dibalik tirai tentang kelahirannya.

Istri Nabi Ibrahim bernama Sarah merupakan sepupu pertama Ibrahim, yaitu anak perempuan paman dari pihak bapaknya yang bernama Haran. Haran merupakan penguasa wilayah Haran yang masyarakatnya merupakan kelompok penyembah bintang yang dilewati oleh Ibrahim dalam perjalanan Mesopotamia menuju Palestina. Sarah menjadi pengikut pertama Nabi Ibrahim dalam mengimani kenabiannya (Katsir, n.d.).

Namun untuk kisah istri yang kedua, al-Qur'an tidak menjelaskannya secara detail. Ia merupakan seorang istri yang menemani Ibrahim saat membangun Ka'bah. Ia merupakan istri yang memiliki posisi sangat penting dalam menjlankan misi kenabian Ibrahim. Dia ikut serta dalam membangun monoteisme yang benar, dia juga menjadi nenek moyang ahli waris Nabi Ibrahim (Katsir, n.d.).

3. Istri Fir'aun

Istri Fir'aun terdapat dua kali dalam al-Qur'an, yaitu QS. al-Qasas (28): 9 dan QS. al-Tahrim (66): 11. Ayat yang pertama merupakan bagian dari kisah Nabi Musa dan yang kedua menceritakan kepribadiaanya.

Dan berkatalah isteri Fir'aun: "(Ia) adalah penyejuk mata hati bagiku dan bagimu. Janganlah kamu membunuhnya, mudah-mudahan ia bermanfa 'at kepada kita atau kita ambil ia menjadi anak", sedang mereka tiada menyadari. 
Artinya ayatnya adalah:

Dan Allah membuat isteri Fir 'aun perumpamaan bagi orang-orang yang beriman, ketika ia berkata: "Ya Rabbku, bangunkanlah untukku sebuah rumah di sisi-MU dalam firdaus, dan selamatkanlah aku dari Fir 'aun dan perbuatannya, dan selamatkanlah aku dari kaum yang zhalim.

Ayat di atas menerangkan keadaan orang yang beriman dalam hubungan mereka dengan orangorang kafir, bahwa hubungan mereka itu tidak membahayakan keimanan mereka dan tidak mengurangi kepercayaan mereka kepada Allah swt. Selain itu, bahwa istri Fir'aun merupakan istri yang beriman pada hari kebangkitan, bahkan ketika ia menyaksikan tongkat Nabi Musa ia mengimaninya dan akhirnya Fir'aun menyiksanya.

Istri Fir'aun ini dikenal sebagai ibu angkat Nabi Musa. Ia merupakan perempuan yang beriman kepada Allah swt. Dialah orang yang menyelamatkan Nabi Musa dari Sungai Nil dan mengangkatnya dari kecil di bawah pengawasan Allah swt. dalam rumahtangga seorang musuh Allah swt. dengan kesalehannya serta mendapatkan wahyu dari Allah sehingga ia menjadi teladan bagi orang-orang yang beriman.

Dengan mendapatkan petunjuk dari Allah, Asia selalu mendukung perjuangan Nabi Musa anak angkatnya. Perjuangannya berakhir pada kematiannya setelah mendapatkan siksa yang sangat pedih dari Fir'aun dan bala tentaranya. Oleh sebab itu maka Allah mengabadikan kisah Asia ini dalam alQur'an agar menjadi teladan bagi perempuan yang beriman dan berjuang di jalan Allah swt. (Syalabi, n.d.).

4. Istri al-'Azij

Istri 'Azij ini merupakan seorang istri dari salah seorang pembesar kerajaan Mesir pada kisan Nabi Yusuf. Ia merupakan perempuan yang cantik, banyak harta dan merupakan bangsawan. Perempuan ini diabadikan oleh Allah dalam QS. Yusuf (12): 21-51 yang artinya:

Dan orang Mesir yang membelinya berkata kepada isterinya (Orang Mesir yang membeli Yusuf a.s. itu seorang Raja Mesir bernama Qithfir dan nama isterinya Zulaikha) "Berikanlah kepadanya tempat (dan layanan) yang baik, boleh jadi dia bermanfaat kepada kita atau kita pungut dia sebagai anak." Dan demikian pulalah Kami memberikan kedudukan yang baik kepada Yusuf di muka bumi (Mesir), dan agar Kami ajarkan kepadanya ta 'bir mimpi. Dan Allah berkuasa terhadap urusan-Nya, tetapi kebanyakan manusia tiada mengetahuinya.

Menurut Imam al-T\{abari, perempuan yang ada dalam kisah Yusuf ini mengacu pada nama yang disebutkan dalam al-Qur'an, yaitu imraah al-'azij (Al-Tabari, n.d.). 'Azij merupakan julukan bagi Qithfir atau Potifar yang merupakan kepala pengawal Fir'aun yang membeli Nabi Yusuf. Imraah al'azij digambarkan sebagai perempuan yang tidak terpuaskan nafsunya oleh suaminya sendiri. Sehingga ia berkeinginan untuk menyalurkannya dengan orang lain, ia pun tidak segan-segan untuk melakukan tipu daya karena keinginannya tidak tersalurkan.

Gambaran tentang imraah al-'azij sebagai majikan Nabi Yususf yang bernama Zulakha ini sangat menonjol dengan segala kompleksitasnya. Mulai dari hawa nafsu, kelicikan, cinta, pertaubatan, kejujuran, dan kesetiaan. Kisah al-Qur'an ini merupakan gambaran bagi sifat-sifat buruk dan baik dari perempuan.

5. Istri ‘Imran

Istri 'Imran ini disebutkan dalam al-Qur'an, yaitu dalam QS. Ali 'Imran (3): 35. Ia merupakan ibunda Maryam yang menjadi ibunda Nabi 'Isa. Adapun ayat yang memuat istri 'Imran adalah sebagai berikut:

(Ingatlah), ketika isteri 'Imran berkata: "Ya Tuhanku, sesungguhnya aku menazarkan kepada Engkau anak yang dalam kandunganku menjadi hamba yang saleh dan berkhidmat (di Baitul Maqdis). Karena itu terimalah (nazar) itu dari padaku. Sesungguhnya Engkaulah Yang Maha Mendengar lagi Maha Mengetahui." Maka tatkala isteri 'Imran melahirkan anaknya, diapun berkata: "Ya Tuhanku, sesungguhnya aku melahirkannya seorang anak perempuan; dan Allah lebih mengetahui apa yang dilahirkannya itu; dan anak laki-laki tidaklah seperti anak perempuan. 
Sesungguhnya aku telah menamai dia Maryam dan aku mohon perlindungan untuknya serta anak-anak keturunannya kepada (pemeliharaan) Engkau daripada syaitan yang terkutuk.

Dalam ayat di atas, 'Imran dan keluarganya termasuk orang yang dipilih oleh Allah swt. untuk mendapatkan anugrah-Nya melebihi umat yang hidup di masanya. Dapat dilihat dari pengabdian yang ia lakuan yaitu menazarkan anak yang ada dalam rahimnya menjadi hamba yang semata-mata mengabdi kepada Allah di Bait al-Maqdis. Namun ketika ia melahirkan dan ternya bayinya perempuan, ia berkata dengan sedikit kecewa, "Tuhanku, aku melahirkan perempuan". Setelah ia melahirkan maka bayi itu diberi nama Maryam. Lalu ia menunaikan nazarnya itu dengan menyerahkan Maryam atas pengasuhannya kepada Zakariya.

Istri 'Imran ini memerankan peranan wanita yang saleh. Sejak hamil ia sudah bercita-cita memiliki anak yang dididik dalam kesucian dan jauh dari pengaruh dan godaan setan (Shihab, 2000).

c. Perempuan Sebagai Kepala Pemerintah

Tokoh perempuan yang digambarkan sebagai kepala pemerintahan adalah Ratu Saba yang terdapat dalam kisah Nabi Sulaiman, sebagaimana dijelaskan dalam QS. al-Naml (27): 23-24 yang artinya:

Sesungguhnya aku menjumpai seorang wanita (Yaitu ratu Balqis yang memerintah kerajaan Sabaiyah di zaman Nabi Sulaiman.) yang memerintah mereka, dan dia dianugerahi segala sesuatu serta mempunyai singgasana yang besar. Aku mendapati dia dan kaumnya menyembah matahari, selain Allah; dan syaitan telah menjadikan mereka memandang indah perbuatanperbuatan mereka lalu menghalangi mereka dari jalan (Allah), sehingga mereka tidak dapat petunjuk.

Pada ayat di atas dijelaskan bahwa burung Hud-Hud membawa berita kepada Nabi Sulaiman tentang seorang ratu (Bilqis bintu Syarahil) yang berkuasa penuh di negerinya dan mempunyai singgasana yang agung. Selain itu dia juga merupakan ratu yang gemar bermusyawarah dengan para pejabat kerajaan. Namun dia bersama pengikutnya menyembah matahari serta amal perbuatannya dihiasi oleh setn dengan kesia-siaan dan mereka tidak mendapatkan petunjuk yang benar.

Pada suatu waktu Nabi Sulaiman mendapat kabar keberadaan Ratu Bilqis dan rakyatnya yang tidak percaya Allah swt. Mereka merupakan kelompok penyembah matahari. Berdasarkan pertimbangan tersebut, Nabi Sulaiman mengirim surat kepada Ratu Bilqis dan mengundangnya untuk berbincang serta beriman kepada Allah swt. sebagaimana tertulis dalam QS. al-Naml (27) ayat 30-31 yang artinya: "Dengan Nama Allah Yang Maha Penyayang dan Maha Pengasih. Jangan bertindak sombong, dan datanglah kepada saya untuk berkomitmen (hidup dalam) damai.

Setelah menerima surat dari Nabi Sulaiman, Ratu Bilqis tidak langsung memenuhi undangan tersebut, ia memilih menghubungi penasihatnya untuk membicarakan surat dari Nabi Sulaiman. Namun para perwira militer Bilqis malah menyarankan tindakan militer dan membalas surat Nabi Sulaiman, sebgaimana terdapat dalam QS. al-Naml (27) ayat 33 yang artinya: "Mereka menjawab: "Kita adalah orang-orang yang memiliki kekuatan dan (juga) memiliki keberanian yang sangat (dalam peperangan), dan keputusan berada ditanganmu: maka pertimbangkanlah apa yang akan kamu perintahkan".

Jawaban Ratu Bilqis saat itu diketahui sangat bijak. Dia berkata jika Sulaiman hanya seorang raja, mereka akan memuaskannya dengan hadiah. Tetapi jika dia seorang Nabi, seperti yang dikatakan pada Bilqis, maka Bilqis menyatakan akan menghadapinya dengan sangat hati-hati. Mendapat kabar dari Ratu Bilqis, Nabi Sulaiman menolak hadiah tersebut, sehingga Bilqis memutuskan untuk menemui Nabi Sulaiman. Akhir dari kisah ini, Ratu Bilqis beriman dan menikah dengan Nabi Sulaiman (Mushodiq, 2018).

Berdasarkan teori Baarthes yang sudah dikemukakan, maka dari symbol-simbol perempuan yang telah dikisahkan di atas, yang dapat diperoleh bahwa dalam sistem linguistic (I) kata yang terdapat pada kisah di atas sebagai signifier, sedangkan signified-nya adalah tokoh itu sendiri. Sedangkan pada sistem mitos (II), signifier-nya adalah kata tokoh-tokoh dalam kisah perempuan itu sendiri beserta seluruh kejadian yang menyertainya dan hakikat para tokoh itu. Adapun signified-nya sebagai berikut: 
1. Simbol Zauj tidak menunjukan bahwa Hawa yang menyebabkan Adam lalai, melainkan kesetaraan antara keduanya. Hal ini dapat dilihat dari huruf 'ataf wawu yang menunjukan persamaan kedudukan.

2. Simbol imraah menunjukan peran perempuan sebagai pendamping suami, hal ini terbagi tiga kategori:

a. Istri yang menghianati suaminya, meskipun suaminya seorang nabi.

b. Istri yang taat terhadap suami yang merupakan nabi.

c. Istri yang menentang suami yang melakukan kedzaliman.

Karakter perempuan di atas merupakan perempuan yang menjadi mitra suami, buka hanya sebagai pasangan.

3. Simbol ratu yang menunjukan bahwa perempuan pun dapat menyelenggarakan pemerintahan secara adil, bijaksana, dan mengerti tentang kesejahteraan rakyatnya.

Dari pembahasan di atas dapat kita ketahui bahwa dari asal kejadiannya laki-laki dan perempuan memiliki persamaan, yaitu sama-sama dari tanah. Namun dari segi tugas dan tanggung jawab, dari segi fisik dan mental keduanya memiliki perbedaan.

Secara fisik, perempuan memiliki tubuh yang lemah-gemulai, halus, cantik dan sebagainya. Sedangkan laki-laki bertubuh kasar, kekar, perkasa dan sebagainya. Bahkan perempuan yang bisa melahirkan. Perbedaan tersebut dijelaskan juga dalam QS. Ali ‘Imran (3): 36:

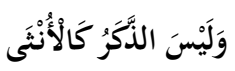

Abi Jahrah menjelaskan dalam Tafsir Jahrah Tafasir, bahwa laki-laki dan perempuan memiliki perbedaan, baik dalam kemulyaan, kedudukan maupun dalam hal ibadah (Jahrah, n.d.). Imam Jamaluddin al-Qasimi juga menjelaskan bahwa diantara perbedaan laki-laki dan perempuan adalah fisik laki-laki lebih kuat dan lebih kekar daripada fisik perempuan (Jahrah, n.d.).

Selain perbedaan fisik, perbedaan lain antara laki-laki dan perempuan adalah perbedaan mental (tabi'at). Perempuan tabi'atnya lemah-lembut, bahasanya halus, suaranya merdu, dan sebagainya. Sedangkan tabi' at laki-laki adalah kasar, keraas, pemberani, dan sebagainya. Dari hasil penelitian yang dilakukan oleh Cleo Dalson menghasilkan bahwa perempuan berada dibawah perintah perasaannya, sedangkan laki-laki berada pada pertimbangan pikirannya (Mardan, 2013).

Perbedaan yang lainnya adalah perbedaan tugas dan tanggung jawab. Perbedaan fisik laki-laki dan perempuan mengakibatkan perbedaan tugas dan tanggung jawab, seperti hamil, melahirkan, menyusui dan lain sebagainya, itu merupakan tugas yang diberikan kepada perempuan. Sedangkan tugas mencari nafkah untuk kebutuhan keluarga adalah tugas laki-laki, sebagaimana dijelaskan dalam QS. al-Nisa (4) ayat 34 .

Namun di sisilain, laki-laki dan perempuan juga memiliki persamaan, sperti persamaan status. Artinya, secara empirik laki-laki dan perempuan memiliki kesamaan dari setatus sebagai manusia. Mereka berasal dari entitas yang sama, sebagaimana dijelaskan dalam QS. al-Nisa (4) ayat 1. Persamaan lainnya adalah tanggung jawab dalam suatu tugas, mereka memiliki tanggung jawab yang sama. Artinya dihadapan hukum mereka memiliki posisi yang sama. Yang berbuat baik akan mendapatkan balasan dan yang berbuat salah akan mendapat hukuman. Hal ini dijelaskan dalam QS. al-Nahl (16) ayat 97. Persamaan yang lainya dalam hal pendidikan. Mereka memiliki persamaan dalam memperoleh pendidikan, sebagaimana dalam HR. Bukhari yang artinya "Siapa saja yang mempunyai anak perempuan lalu ia mendidiknya dengan baik, maka anak itu akan menjadi tabir yang melindunginya dari api neraka". Kemudian dalam hal pekerjaan pun mereka memiliki kesempatan yang sama, bahkan al-Qur'an mengajarkan bahwa perempuan tidak boleh dipekerjakan secara diskriminasi. Al-Qur'an tidak melarang perempuan bekerja uantuk mencari kekayaan agar ia bisa membayar zakat, sebagaiman dijelaskan dalam QS. al-Taubah (9) ayat 71.

\section{Kesimpulan}

Sebelum al-Qur'an diturunkan, perempuan merupakan kaum yang mendapatkan diskriminasi dan tidak memiliki kebebasn seperti laki-laki. Misalkan pada masa Yunani, mereka hanya dijadikan budak yang diperjual belikan. Begitupun di masa Romawi, mereka ada dalam kuasa ayahnya atau 
suaminya. Lebih parah lagi di kalangan Hindu dan Cina, mereka harus ikut dibakar hidup-hidup saat pembakaran mayat suami. Dalam fakta sejarah ditemuka, bahwa sebelum datangnya Islam kondisi perempuan memang sangat suram. Sejarah menjadi saksi bagaimana perempuan yang melahirkan manusia justru malah dihinakan. Situasi dan kondisi di atas ternyata tidak sejalan dengan apa yang diajarkan al-Qur'an.

Untuk menggali kedudukan perempuan dalam al-Qur'an maka dilakukan penelitian dengan pendekatan semiotika Rolan barthes, yang merupakan merupakan pengembangan dari semiologi Saussure. Menurut Barthes, semiologi Saussure merupakan sistem semiologi tahap pertama yang perlu dikembangkan tahap selanjutnya yang menjadi tahap kedua. Menurutnya tahap pertama disebut sistem linguistik dan tahap yang kedua disebut sistem mitis (mitos). Mitos diasumsikan sebagai sistem penanda yang dibangun berdasarkan tiga hal, yaitu penanda (signifier), petanda (signified), dan tanda (sign).

Penelitian dengan teori Barthes terhadap simbol perempuan dalam al-Qur'an dilakukan dengan meneliti kata Zauj, imraah, dan perempuan sebagai ratu (ratu Bilqis). Simbol perempuan sebagai zauj dalam al-Qur'an diperankan oleh Zauj Adam (pasangan Nabi Adam) yang disebutkan dalam al-Qur'an sebanyak lima kali dengan lafaz zaujuka. Adapun simbol imraah yang terdapat dalam al-Qur'an diperankan oleh istri Nabu Lut, istri Nabi Ibrahim, istri Fir'aun, istri pembesar kerajaan (Imra'ah al'Aziz) yang terdapat pada kisah Nabi Yusuf, dan istri Imran.

Penelitian dari simbol di atas mengarah pada persamaan dan perbedaan antara laki-laki dan perempuan. Pada satu keadaan mereka sama, tetapi pada keadaan lain mereka berbeda. Mereka memiliki persamaan dalam hal asal kejadiannya, yaitu sama-sama dari tanah, kesamaan dari setatus sebagai manusia, persamaan dalam hal tanggung jawab, persamaan dalam hal kelayakan pekerjaan, dan lain sebagainya. Namun dari segi tugas dan tanggung jawab, dari segi fisik, mental keduanya memiliki perbedaan.

\section{Referensi}

'Abdullah, M. Y. (1985). Qadaya' Al-Mar'ah fi Suirah alNisa. Kuwait: Dâr al-Dakwah.

Adawiah, R. (2013). Aisyiyah dan Kiprahnya dalam Pembinaan Keluarga Sakinah. Mu'adalah; Jurnal Studi Gender Dan Anak, 1(2), 97-116.

Al-Syuyuthi. (2008). Al-Itqan fi 'Ulum al-Qur'an. Kairo: Darussalam.

Al-Tabari, A. J. (n.d.). Jami' al-Bayan fi Ta'wil al-Qur'an. aplikasi Maktabah Syamilah.

Al-Zuhaili, W. bi M. (n.d.). Tafsir al-Wasit. Aplikasi Maktabah Syamilah.

Jahrah, A. (n.d.). Tafsir Jahrah Tafasir. Aplikasi Maktabah Syamilah.

Katsir, A. al-F. I. bin. (n.d.). Tafsir al-Qur'an al-Karim (Tafsir Ibnu Katsir). Aplikasi Maktabah Syamilah.

Kuswana, D., Qomaruzzaman, B., \& Mahatma, M. (2020). Agama dan wabah: Tanggapan ulama Jawa Barat atas Covid19 tahun 2020. UIN Sunan Gunung Djati Bandung.

Mardan. (2013). Semiotika Perempuan dalam Kisah al-Quran. Jurnal Adabiyah, 13(1), 10-35.

Mushodiq, M. A. (2018). Representamen Cinta Dalam Kisah Nabi Sulaiman Dan Ratu Saba'Surat An-Naml (Studi Analisis Semiotika Dan Komunikasi Interpersonal). Al-Tsaqafa: Jurnal Ilmiah Peradaban Islam, 15(2), $243-257$.

Muththalib, R. F. 'Abdul. (n.d.). Tautsî̀ al-Sunnat fi alQur'ân al-Tsâniy. Mishr: al-Kanji.

Nasir, A. (2016). Keteladanan Perempuan Dalam Sastra Qur'ani: Analisis Kritik Sastra Feminis Kisah Perempuan Dalam Al Quran. Palastren: Jurnal Studi Gender, 6(2), 277-298.

Nasrulloh, Mainna, L., Kuswana, D., \& Shodiqin, A. (2017). Implementasi Pesan Dakwah melalui Radio Streaming dan Pemahaman Keagamaan Mad'u. Tabligh: Jurnal Komunikasi Dan Penyiaran Islam, 2(1), 1-21.

Rahman, M. T. (2010). Pluralisme Politik. WAWASAN: Jurnal Ilmiah Agama Dan Sosial Budaya, 34(1), 1-13.

Rahman, M. T. (2016). Rasionalitas Sebagai Basis Tafsir Tekstual (Kajian atas Pemikiran Muhammad Asad). AlBayan: Jurnal Studi Al-Qur'an Dan Tafsir, 1(1), 63-70.

Rahman, M. T., Ziaulhaq, M., Rosyad, R., Truna, D. S., Ridwanudin, P., Philips, G., \& Wibisono, M. Y. (2020). Webinar Internasional:"Earth Today: Between Religion, Ecology, and Ecocide.

Rosyad, R. (2007). A quest for true Islam: A study of the Islamic resurgence movement among the youth in Bandung, Indonesia. Australia: ANU Press.

Rosyad, R., Mubarok, M. F., Rahman, M. T., \& Huriani, Y. (2021). Toleransi Beragama dan Harmonisasi Sosial. Bandung: Digital Library UIN Sunan Gunung Djati Bandung.

Rusmana, D. (2014). Filsafat Semiotika. Bandung: Pustaka Setia. 
Sanusi, S. (2011). Semiotika al-Qur'an: Pendekatan Baru Studi Islam (Telaah atas Asma'al-Qur'an). Jurnal IndoIslamika, 1(2), 153-163.

Sawali. (2007). Memaksimalkan Peran Ibu Sebagai Pencerah Peradaban.

Shihab, M. Q. (1996). Wawasan Al-Quran: Tafsir Tematik atas Pelbagai Persoalan Umat. Mizan Pustaka.

Shihab, M. Q. (2000). Tafsir al-Mishbah. Jakarta: Lentera Hati.

Shihab, M. Q. (2007). 'Membumikan' Al-Quran: fungsi dan peran wahyu dalam kehidupan masyarakat. Mizan Pustaka. Sudarmono. (1998). Bahan Penataran P-4: Garis-Garis Besar Haluan Negara. Jakarta: BP-7 Pusat.

Sudarto, A. D., Senduk, J., \& Rembang, M. (2015). Analisis Semiotika Film “Alangkah Lucunya Negeri Ini". Acta Diurna, 4(1), 1-11.

Sukmadinata, N. S. (2019). Landasan psikologi proses pendidikan. Bandung: PT Remaja Rosdakarya.

Syalabi, M. (n.d.). Hayatu Asiyah Imra'atu Fir'aun.

Taufik, A. (1989). Metode Penelitian Agama Sebuah Pengantar. Yogyakarta: PT. Tiara Wacana Yogya.

Taufiq, W. (2016). Semiotika untuk Kajian Sastra dan al-Qur'an. Bandung: Yrama Widya.

Wibisono, M. Y. (2020). Sosiologi Agama. Prodi P2 Studi Agama-Agama UIN Sunan Gunung Djati Bandung.

(C) 2021 by the author. Submitted for possible open access publication under the terms and conditions of the Creative Commons Attribution (CC BY SA) license (https://creativecommons.org/licenses/by-sa/3.0/). 